Article

\title{
Investigation of the Properties of Ti-TiN-(Ti,Cr,Mo,Al)N Multilayered Composite Coating with Wear-Resistant Layer of Nanolayer Structure
}

\author{
Sergey Grigoriev ${ }^{1}\left(\mathbb{D}\right.$, Alexey Vereschaka ${ }^{2, *}$,, Filipp Milovich ${ }^{3}$, Nikolay Sitnikov ${ }^{4}$, \\ Nikolay Andreev ${ }^{3}$, Jury Bublikov ${ }^{2}$, Catherine Sotova ${ }^{1} \mathbb{1}$, Gaik Oganian ${ }^{1}$ and Ilya Sadov ${ }^{1}$ \\ 1 VTO Department, Moscow State Technological University STANKIN, 127994 Moscow, Russia; \\ s.grigoriev@stankin.ru (S.G.); e.sotova@stankin.ru (C.S.); svartrans88@yandex.ru (G.O.); \\ sadvilj@yandex.ru (I.S.) \\ 2 Institute of Design and Technological Informatics of the Russian Academy of Sciences (IDTI RAS), \\ 127994 Moscow, Russia; yubu@rambler.ru \\ 3 Materials Science and Metallurgy Shared Use Research and Development Center, National University of \\ Science and Technology MISiS, 119049 Moscow, Russia; filippmilovich@mail.ru (F.M.); \\ andreevn.misa@gmail.com (N.A.) \\ 4 Department of Solid State Physics and Nanosystems, National Research Nuclear University MEPhI, \\ 115409 Moscow, Russia; sitnikov_nikolay@mail.ru \\ * Correspondence: dr.a.veres@yandex.ru
}

Received: 9 November 2020; Accepted: 13 December 2020; Published: 16 December 2020

\begin{abstract}
The article describes the results of an investigation focused on the properties of the Ti-TiN-(Ti,Cr,Mo,Al)N multilayered composite coating with a wear-resistant layer of nanolayer structure. A transmission electron microscope was used to study the coating structure. The examination of the phase composition using selected area diffraction electron pattern has detected the presence of two phases, including c-(Ti,Cr,Mo,Al)N and h-AlN. The cutting properties of the tool with the coating under consideration were studied during the turning of AISI 1045 steel at $\mathrm{v}_{\mathrm{c}}=300 \mathrm{~m} / \mathrm{min}, \mathrm{f}=0.25 \mathrm{~mm} / \mathrm{rev}$, and $\mathrm{a}_{\mathrm{p}}=1.0 \mathrm{~mm}$. After $16 \mathrm{~min}$ of cutting, the wear rate for the tool with the Ti-TiN-(Ti,Cr,Mo,Al)N coating was 1.9 times lower compared to the wear rate for the tool with the $(\mathrm{Ti}, \mathrm{Al}) \mathrm{N}$ commercial monolithic coating. As a result of the investigation focused on the fracture pattern on the coating during the cutting, the brittle nature of the fracture has been detected with a noticeable effect of adhesive fatigue mechanisms.
\end{abstract}

Keywords: nanolayered coating; microparticles; crack formation; tool wear

\section{Introduction}

Modified coatings developed for various purposes, particularly coatings for metal-cutting tools, are being actively implemented in various areas of manufacturing activity. At the same time, the trends of modern manufacturing suggest toughening requirements for coatings. In particular, an increase in the cutting speed leads to an increase in temperature in the cutting zone, and, accordingly, the crucial feature of the coatings is heat resistance [1-5]. With an increase in temperature, oxidation and diffusion processes become more active and intensify tool wear [6-10]. Accordingly, one of the significant factors is the ability of a coated tool to resist the oxidation and diffusion wear. The coatings of traditional composition, such as $\mathrm{TiN}, \mathrm{TiC}, \mathrm{ZrN}, \mathrm{CrN}$, or $(\mathrm{Ti}, \mathrm{Al}) \mathrm{N}$, can no longer meet the requirements of the modern manufacturing, and new coatings with enhanced properties are required. One of the ways to 
develop such coatings is to use a multicomponent composition and nanolayer architecture [11-15]. In particular, the introduction of such elements as $\mathrm{Cr}$ and Mo into the coating composition increases its resistance to heat and oxidation and diffusion effects. The coatings based on the (Ti,Al)N system are used rather widely, like nitride coatings containing $\mathrm{Cr}$ and Mo. However, fewer studies have considered the coatings based on the multicomponent nitrides, including a complex of these elements.

Regent and Musil [16] investigated the (Ti,Mo)N and $(\mathrm{Ti}, \mathrm{Cr}) \mathrm{N}$ coatings. The hardness of the (Ti,Mo)N coating was 38-40 GPa with the content of molybdenum (Mo) up to 10 at.\%), and the $\delta$-TiN phase (111) with miscible Mo dominated in the coating structure. The study of the (Ti,Cr) N coating detected the presence of the solid solution of $(\mathrm{Ti}, \mathrm{Cr}) \mathrm{N}(200)$ and $\mathrm{Cr}_{2} \mathrm{~N}(111)$, while the phases of TiN (111), (Ti,Mo)N (200), $\mathrm{Mo}_{2} \mathrm{~N}$ (111), and pure Mo were detected in the (Ti,Mo)N coating [17]. Moreover, the authors suggest that the phase of pure molybdenum in the $(\mathrm{Ti}, \mathrm{Mo}) \mathrm{N}$ coating can significantly reduce the coefficient of friction (COF) in comparison with the $(\mathrm{Ti}, \mathrm{Cr}) \mathrm{N}$ and $\mathrm{TiN}$ coatings [17]. The study focused on the properties of the $(\mathrm{Ti}, \mathrm{Cr}) \mathrm{N}$ coating also found that the introduction of chromium $(\mathrm{Cr})$ into the composition of the TiN coating is able to significantly increase the oxidation resistance due to the formation of dense chromium oxide $\left(\mathrm{Cr}_{2} \mathrm{O}_{3}\right)$ on the coating surface $[18,19]$. This oxide is characterised by high heat resistance and does not transform into chromium trioxide $\left(\mathrm{CrO}_{3}\right)$ until the temperature reaches $1100^{\circ} \mathrm{C}[20]$.

During the studies of the (Cr,Mo)N coating, the phases of fcc-CrN (111) and (200) and amorphous/nanocrystalline $\mathrm{Mo}_{2} \mathrm{~N}$ were found, but no expected substitutional solid solution of $(\mathrm{Cr}, \mathrm{Mo}) \mathrm{N}$ was detected [21]. Experiments carried out by Kim et al. [22] revealed the substitutional solid solution $(\mathrm{Cr}, \mathrm{Mo}) \mathrm{N}$ with the Mo content of less than 30.4 at. $\%$, and the maximum hardness of the coating ( $34 \mathrm{GPa}$ ) was achieved with the Mo content of 21 at.\%. The studies also note that the phases formed in this coating depend on the nitrogen-to-argon ratio in a chamber. With an increase in the nitrogen content, a single fcc solid solution $(\mathrm{Cr}, \mathrm{Mo}) \mathrm{N}$ phase forms instead of the mixture of bcc hexagonal $(\mathrm{Cr}, \mathrm{Mo}) \mathrm{N}$ phases [23]. During the studies of the coating with alternating $\mathrm{CrN} / \mathrm{Mo}_{2} \mathrm{~N}$ layers, the formation of $\mathrm{MoO}_{3}$ and $\mathrm{Cr}_{2} \mathrm{O}_{3}$ oxides was detected upon heating to $400-500{ }^{\circ} \mathrm{C}$, and it was molybdenum trioxide $\left(\mathrm{MoO}_{3}\right)$ which had a crucial influence on the reduction of friction [24]. In [25-27], the investigation of the (Ti,Al,Mo) N coating revealed the presence of TiN and Mo phases (studied by the X-ray diffraction (XRD) method). A study by the XRD method detected no phase of $\gamma-\mathrm{Mo}_{2} \mathrm{~N}$ which can be explained by the fact that in the X-ray diffraction patterns, the reflections of this phase and the phase of MoN coincide with TiN. However, the phase of $\gamma-\mathrm{Mo}_{2} \mathrm{~N}$ was detected by the X-ray photoelectron spectroscopy (XPS) method. The hardness of the $(\mathrm{Ti}, \mathrm{Al}, \mathrm{Mo}) \mathrm{N}$ coating reaches $40 \mathrm{GPa}$ [28]. The introduction of nickel (Ni) in the composition of the (Ti,Al,Mo) N coating reduced the grain sizes from $40-50$ to $10-12 \mathrm{~nm}$. Meanwhile, at temperatures exceeding $500^{\circ} \mathrm{C}$, the Ni-containing coating wore out more intensively, and in [29], that fact was associated with the formation of the $\mathrm{TiNiO}_{3}$ oxide.

In their previous articles, authors of this paper studied the properties of the coatings with wear-resistant layers, including ( $\mathrm{Ti}, \mathrm{Cr}, \mathrm{Al}) \mathrm{N}$ [30-32], $(\mathrm{Zr}, \mathrm{Nb}, \mathrm{Cr}, \mathrm{Al}) \mathrm{N}$ [30,32], (Zr,Nb, Ti)N [32], $(\mathrm{Zr}, \mathrm{Cr}, \mathrm{Al}) \mathrm{N}$ [32], (Nb,Zr,Ti,Al)N [32], and (Ti,Cr,Al,Si)N [33]. These studies show that the coatings with multi-element compositions often have better performance properties compared to binary and ternary systems.

The studies were focused on the Ti-TiN-(Ti,Cr,Mo,Al)N coating with three-layer architectures according to the recommendations described in in our past works [34,35]. It can be assumed that coating Ti-TiN-(Ti,Cr,Mo,Al)N will have good tribological properties due to the formation of $\mathrm{MoO}_{3}$ and $\mathrm{Cr}_{2} \mathrm{O}_{3}$ oxides with high hardness and wear resistance [18-24,29].

\section{Materials and Methods}

The VIT-2 vacuum plasma unit (IDTI RAS-MSTU STANKIN, Moscow, Russia) $[34,36]$ was used to deposit coatings with the filtered cathodic vacuum arc deposition (FCVAD) technology [34-41]. The VIT-2 unit contained two arc evaporators with a pulsed magnetic field and one arc evaporator 
with filtering of the vapor-ion flow. Moreover, the complex contains a source of pulsed bias voltage supply to a substrate, a dynamic gas mixing system for reaction gases, systems for automatic chamber pressure control and for process temperature control, and a system for the stepless adjustment of planetary gear rotation.

The VIT-2 unit has three cathode systems, in which cathodes of Al 99.1 at.\%, Ti 99.9 at.\% and also of $\mathrm{Cr}-\mathrm{Mo}$ (50-50 at.\%) are installed. Cylindrical cathodes with the diameter of $80 \mathrm{~mm}$ were used. Three cathodes of $\mathrm{Ti}-\mathrm{Al}(80-20$ at. $\%$ ) were used to deposit the (Ti,Al)N commercial coating.

Coating deposition rate is $100 \mathrm{~nm}$ per minute.

The parameters for the process of coating deposition are presented in Table 1.

Table 1. Parameters of stages of the technological process of the deposition of coatings.

\begin{tabular}{ccccccc}
\hline Process & $p_{N}(\mathbf{P a})$ & $U(\mathrm{~V})$ & $\boldsymbol{I}_{T i}$ (A) & $\boldsymbol{I}_{A l}$ (A) & $\boldsymbol{I}_{T i-A l}$ (A) & $\begin{array}{c}\boldsymbol{I}_{C r-M o} \\
\text { (A) }\end{array}$ \\
\hline $\begin{array}{c}\text { Pumping and heating of } \\
\text { vacuum chamber }\end{array}$ & 0.06 & +20 & 75 & 120 & 75 & - \\
\hline $\begin{array}{c}\text { Heating and cleaning of } \\
\text { products with gaseous plasma }\end{array}$ & 2.0 & $\begin{array}{c}100 \mathrm{DC} / 900 \mathrm{AC} \\
f=10 \mathrm{kHz}, 2: 1\end{array}$ & 85 & 80 & 85 & - \\
\hline Deposition of coating & 0.42 & $-800 \mathrm{DC}$ & 75 & 160 & 75 & 120 \\
\hline Cooling of products & 0.06 & - & - & - & - & - \\
\hline
\end{tabular}

Note: $I_{T i}=$ current of titanium cathode, $I_{T i-A l}=$ current of Ti-Al cathode, $I_{A l}=$ current of aluminum cathode,

$I_{\mathrm{Cr}-\mathrm{Mo}}=$ current of $\mathrm{Cr}$-Mo cathode, $p_{N}=$ gas pressure in chamber, $U=$ voltage on substrate.

The nanoindentation technique and an Instron Wilson Hardness Group Tukon tester at the load of $0.01 \mathrm{~N}$ were used to determine the coating microhardness.

During the turning of workpieces made of AISI 1045 steel, a CU 500 MRD lathe (ZMM Sliven, Sliven, Bulgaria) with a ZMM CU500 MRD variable-speed drive (ZMM Bulgaria, Sofia, Bulgaria) was applied. No coolants or lubricants were used during the process of cutting. SNUN ISO 1832:2012 carbide inserts played a role of substrates, with the parameters as follows: $\gamma=-7^{\circ}, \alpha=7^{\circ}, \lambda=0, r=0.4$ mm; cutting mode: $f=0.25 \mathrm{rpm}, a_{p}=1.0 \mathrm{~mm}$, and $v_{c}=300 \mathrm{~m} / \mathrm{min}$. Four experiments were conducted for each coating, and the obtained values of flank wear were processed to get the polynomial functions exhibited on the curve. The limit wear criterion was assumed as flank wear rate $V B_{\max }=0.4 \mathrm{~mm}$. Five tests of cutting properties were carried out, after which the information was statistically processed. Average values were determined for five experiments, these average values were used to plot the graph. Polynomial dependencies were obtained, on the basis of which graphs of the dependence of the flank wear on the cutting time were plotted.

\section{Results and Discussion}

\subsection{Study of the Chemical Composition and Nanostructure of the Ti-TiN-(Ti,Cr,Mo,Al)N Coating}

According to the results of 20 conducted measurements, the average hardness of the coating was 42 $\pm 1.3 \mathrm{GPa}$, which is fairly high for nitride coatings. The coating structure includes an adhesion layer of Ti with the thickness of about $50 \mathrm{~nm}$, a transition layer of TiN with the thickness of about $600 \mathrm{~nm}$, and a wear-resistant layer of (Ti,Cr,Mo,Al)N with the thickness of about $2700 \mathrm{~nm}$ (Figure 1). The thickness of the functional layers of the coating was selected based on their optimal ratio [32,35]. The wear-resistant layer of $(\mathrm{Ti}, \mathrm{Cr}, \mathrm{Mo}, \mathrm{Al}) \mathrm{N}$ is formed by a 22-nanolayer period with $\lambda$ of about $120 \mathrm{~nm}[11,33]$. 


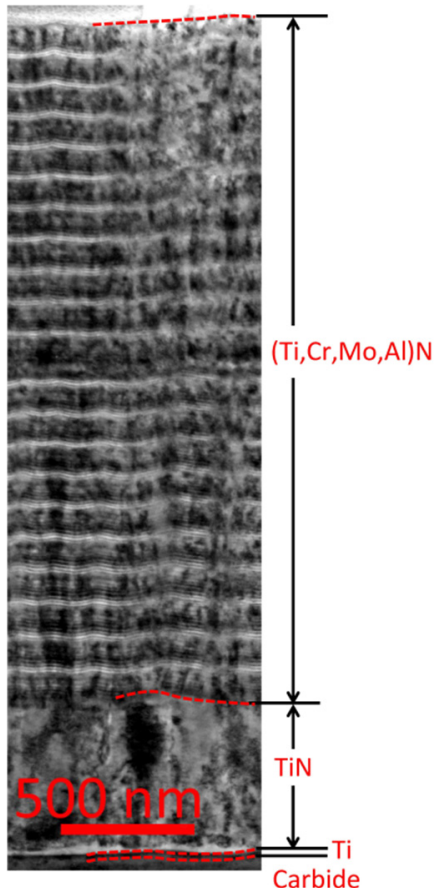

Figure 1. General structure of the Ti-TiN-(Ti,Cr,Mo,Al)N coating (TEM).

The nanostructures of the studied coating Ti-TiN-(Ti,Cr,Mo,Al)N in comparison with the (Ti,Al)N monolayer coating are presented in Figure 2.

Figure 2a illustrates that the nanostructure of Ti-TiN-(Ti,Cr,Mo,Al)N coating includes nanolayers with the high content of $\mathrm{Al}$ (lighter bands) and nanolayers with the high content of $\mathrm{Cr}-\mathrm{Mo}$ and $\mathrm{Ti}$ (darker bands). For Ti-TiN-(Ti,Cr,Mo,Al)N coating, the value of nanolayer period $\lambda[11,33]$ is about $120 \mathrm{~nm}$, and the thicknesses of nanolayers are within a range of 1-8 $\mathrm{nm}$. The results of the studies of the coatings phase compositions using the Selected Area Electron Diffraction (SAED) method are presented in Figure 2c,d.

The analysis of the SAED patterns for coatings Ti-TiN-(Ti,Cr,Mo,Al)N (Figure 2c) detected the presence of two phases. The analysis also found the main cubic phase ( $\mathrm{Ti}, \mathrm{Nb}, \mathrm{Zr}, \mathrm{Al}) \mathrm{N}$ with $\mathrm{Fm} 3 \mathrm{~m}$ space group. Weak reflections with P6.3mc space group belong to the h-AlN phase. Rings of the h-AlN phase are barely noticeable, and that fact may indicate an extremely insignificant volume of the phase.

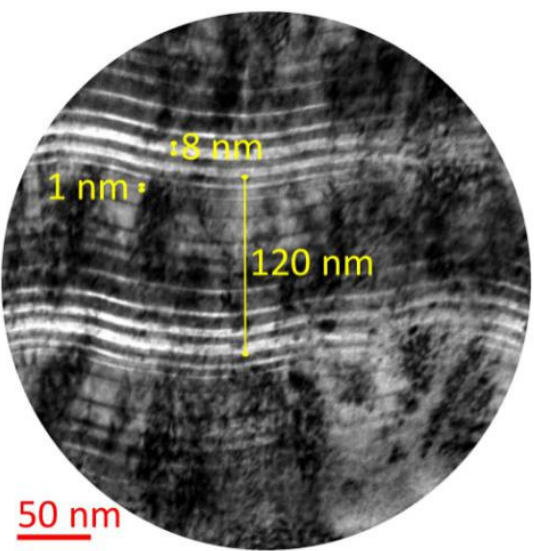

(a)

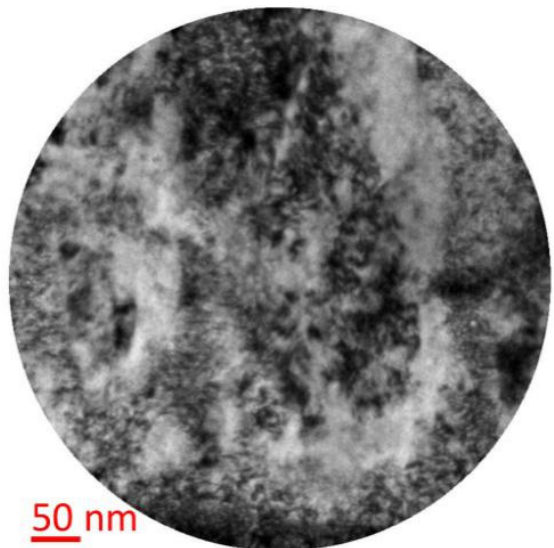

(b)

Figure 2. Cont. 


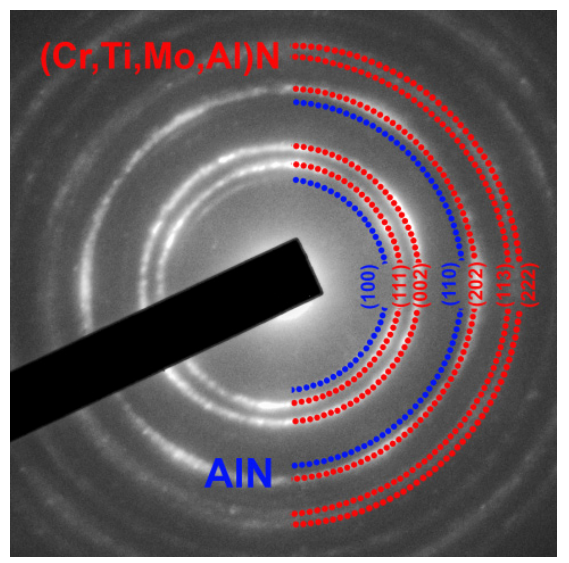

(c)

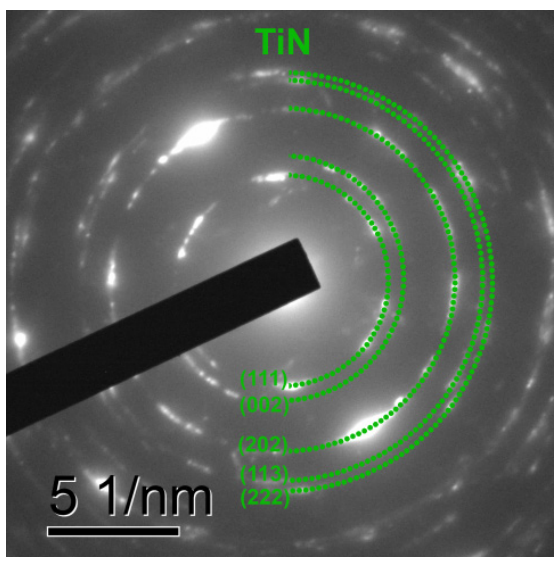

(d)

Figure 2. (a,b) TEM micrograph of coating and (c,d) SAED patterns of the coatings: (a,c) Ti-TiN$(\mathrm{Ti}, \mathrm{Cr}, \mathrm{Mo}, \mathrm{Al}) \mathrm{N}$ and $(\mathbf{b}, \mathbf{d})(\mathrm{Ti}, \mathrm{Al}) \mathrm{N}$ monolayer coating (TEM).

The studies of the chemical composition of the coatings (Figure 3a) found the average contents of elements as follows in coating Ti-TiN-(Ti,Cr,Mo,Al)N:

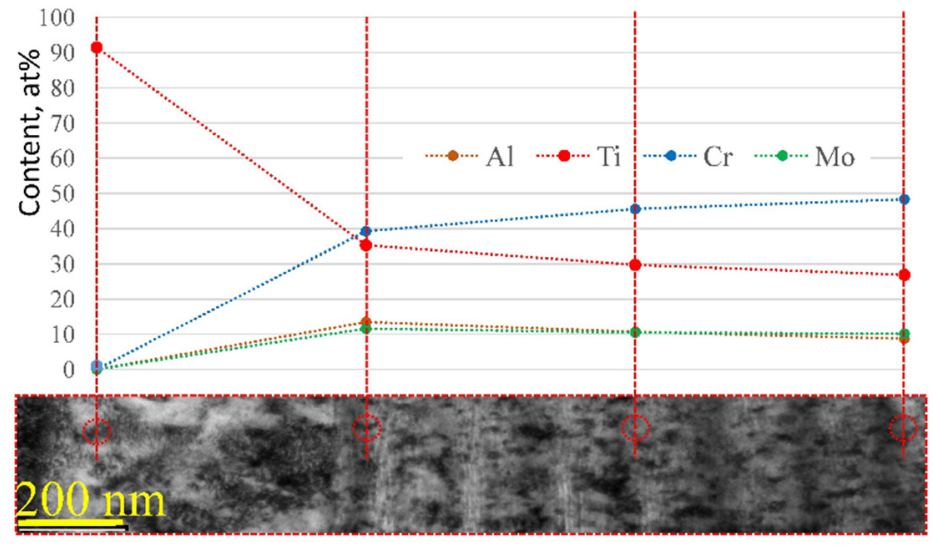

(a)

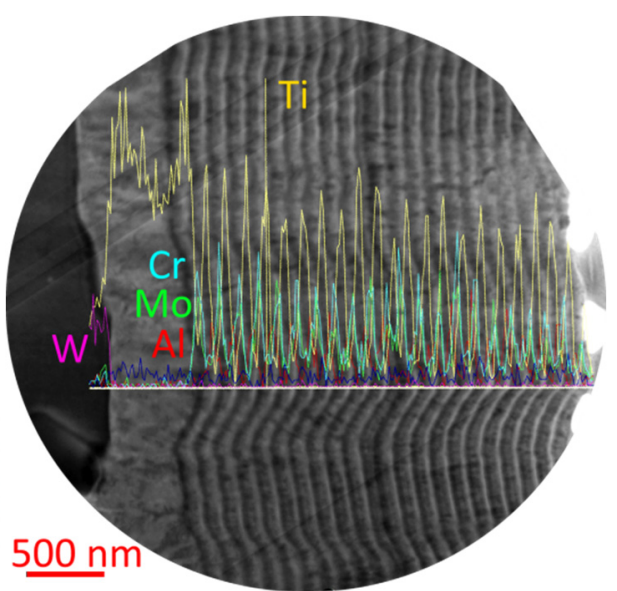

(b)

Figure 3. Distribution of chemical elements over the thickness (a) and change in the content of different elements in nanolayers $(\mathbf{b})$ of coating Ti-TiN-(Ti,Cr,Mo,Al)N.

Ti-22 at. $\%, \mathrm{Cr}-38$ at. $\%, \mathrm{Al}-11$ at. $\%, \mathrm{Mo}-10$ at. $\%$.

The study of the nature of the distribution of elements in the nanolayer periods (Figure $3 \mathrm{~b}$ ) finds that the content of each element changes significantly within a nanolayer period. In particular, the content of Ti changes from 7 to 60 at. $\%$, and the content of $\mathrm{Al}$-from 3 to 27 at.\%. The above ensures a smooth, gradient transition from harder and more wear-resistant layers with the high $\mathrm{Al}$ content to more ductile layers with the low $\mathrm{Al}$ content.

Let us consider the influence of the nanolayer structure of the coating on its crystalline structure. Earlier, it has been found that the nanolayer structure affects the grain sizes by reducing them $[11,33]$. At the same time, the grain size of the coating is not always limited by the boundaries of a nanolayer or a nanolayer period [11]. The Ti-TiN-(Ti,Cr,Mo,Al)N coating under study demonstrates columnar crystals with sizes noticeably larger than the value of nanolayer period (Figure 4a), and the grain structure of the coating can be seen more clearly in the reverse contrast image (Figure $4 \mathrm{~b}$ ). The nanolayer structure of this coating does not stop the growth of crystals (Figure 4c). However, as noted earlier [11,33], 
the presence of the nanolayer structure allows the formation of crystals with significantly smaller sizes than crystals in coatings with monolayer structures. A comparison of SAED patterns on the Ti-TiN-(Ti,Cr,Mo,Al)N nanolayer coating (Figure 2c) and on the (Ti,Al)N monolithic coating (Figure 2d) demonstrates the significantly smaller size of crystals in the Ti-TiN-(Ti,Cr,Mo,Al) N coating.

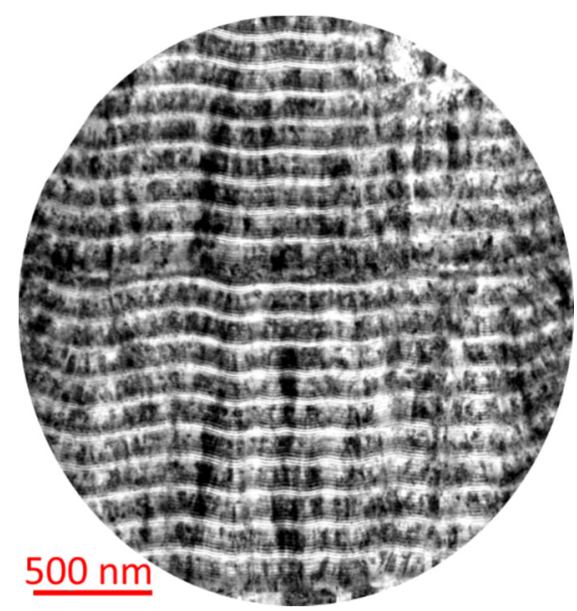

(a)

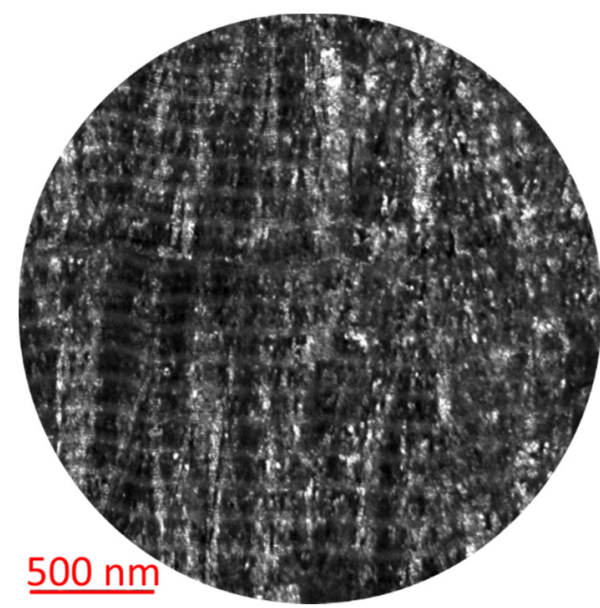

(b)

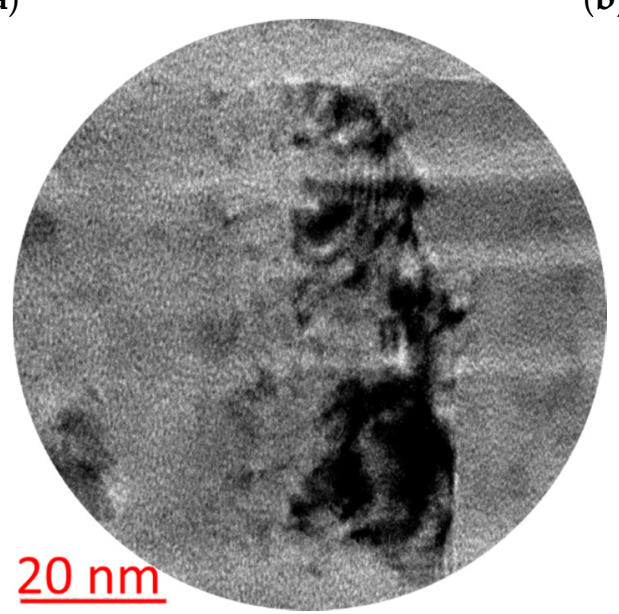

(c)

Figure 4. TEM micrograph of Ti-TiN-(Ti,Cr,Mo,Al)N coating and study of the influence of the nanolayer structure of the coating on its crystalline structure. (a) nanostructure (b) nanostructure in reverse contrast image (c) individual grain in a nanostructure.

Figure 5 presents the high-resolution TEM images of coating Ti-TiN-(Ti,Cr,Mo,Al)N, with noticeable crystals with sizes of 5-15 nm. The analysis of interplanar spacing revealed the presence of two phases of h-AlN and c- $(\mathrm{Cr}, \mathrm{Ti}, \mathrm{Mo}, \mathrm{Al}) \mathrm{N}$. The obtained results are in line with the SAED pattern presented in Figure 2c. 


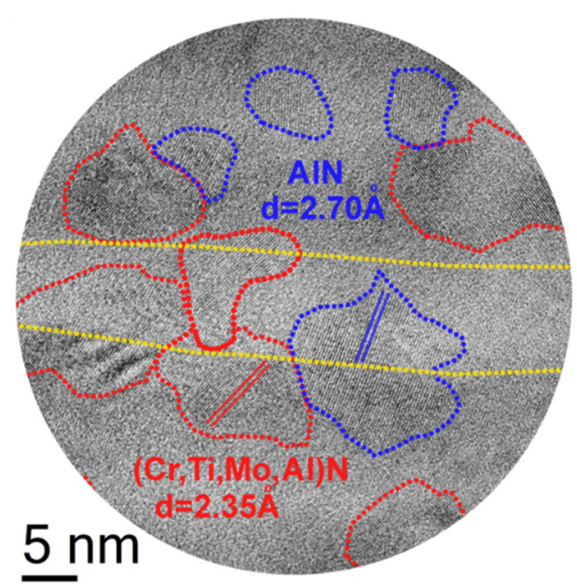

Figure 5. Crystalline structure of coating Ti-TiN-(Ti,Cr,Mo,Al)N (HR TEM).

3.2. Study of the Cutting Properties and the Wear Pattern on Tools with the Ti-TiN-(Ti,Cr,Mo,Al)N Coating

The studies of the cutting properties of the carbide tools found that the use of Ti-TiN-(Ti,Cr,Mo,Al)N coating can significantly reduce the flank wear compared to the tools with the (Ti,Al)N commercial coating. Figure 6 illustrates that after $7 \mathrm{~min}$ of operation, the wear of the carbide inserts with the (Ti,Al)N coating increases sharply, while the inserts with Ti-TiN-(Ti,Cr,Mo,Al)N coating demonstrate much lower wear, and the wear rate decreases.

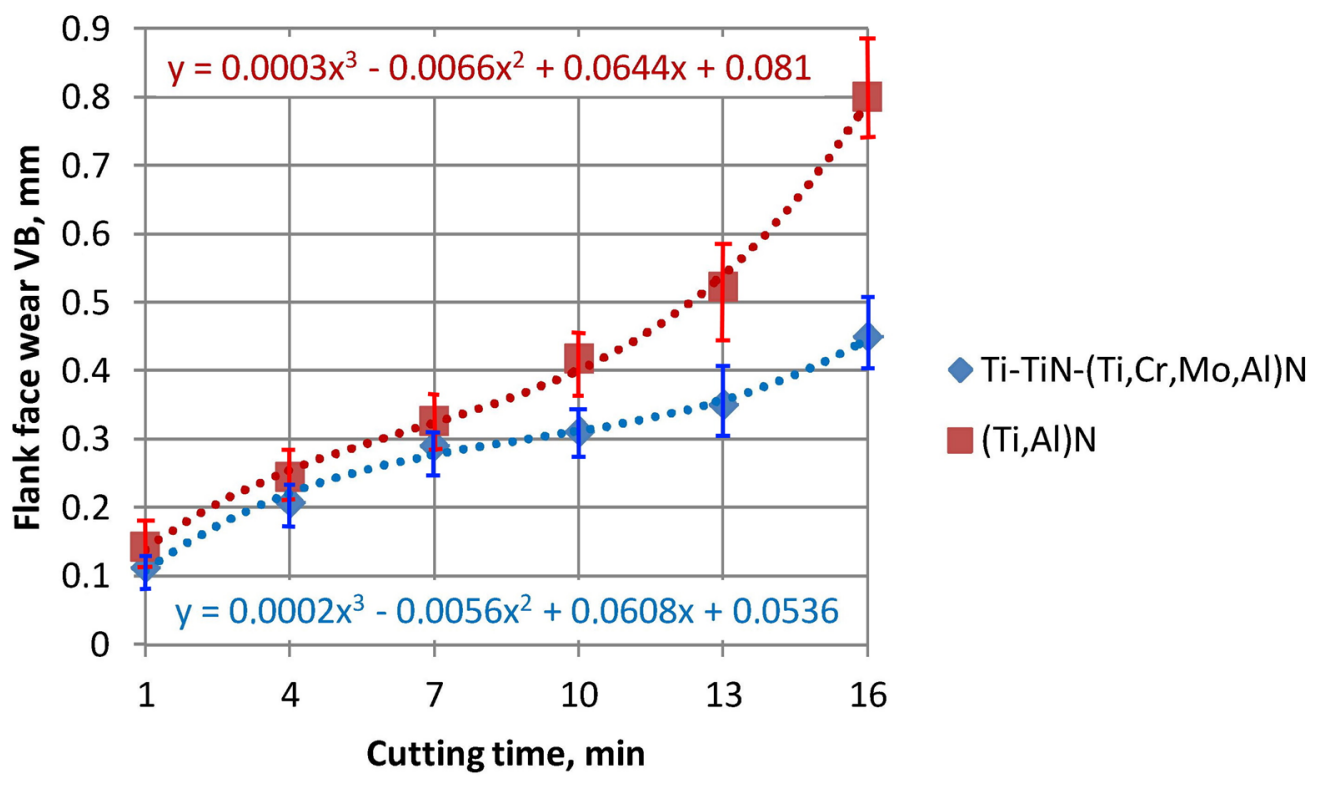

Figure 6. Relation between cutting time and flank wear (VB) on coated carbide tools during the turning of AISI 1045 steel: $\mathrm{v}_{\mathrm{c}}=300 \mathrm{~m} / \mathrm{min}, \mathrm{f}=0.25 \mathrm{~mm} / \mathrm{rev}, \mathrm{a}_{\mathrm{p}}=1.0 \mathrm{~mm}$.

The good wear resistance of the $\mathrm{Ti}-\mathrm{TiN}-(\mathrm{Ti}, \mathrm{Cr}, \mathrm{Mo}, \mathrm{Al}) \mathrm{N}$ coating can be explained by the formation of tribological oxide films of $\mathrm{MoO}_{3}$ and $\mathrm{Cr}_{2} \mathrm{O}_{3}$, which favourably transform the cutting conditions [42-47].

The investigation of wear areas on the rake face of the carbide inserts after 16 min of operation (Figure 7) found that the tool with coating (Ti,Al)N demonstrated the higher rake wear, which manifested itself in the formation of a crater and a notch wear compared to the tool with Ti-TiN-(Ti,Cr,Mo,Al)N coating. 


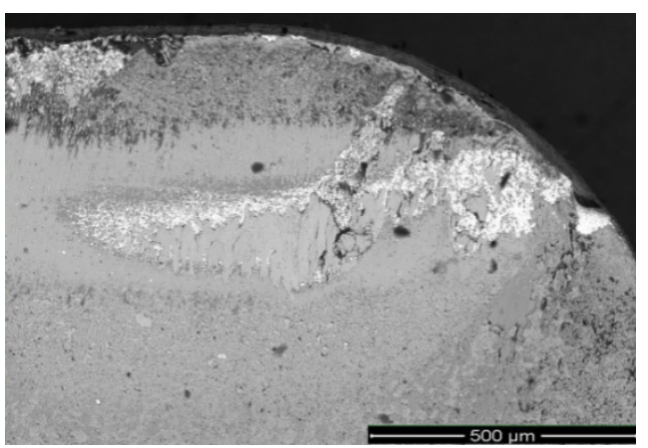

(a)

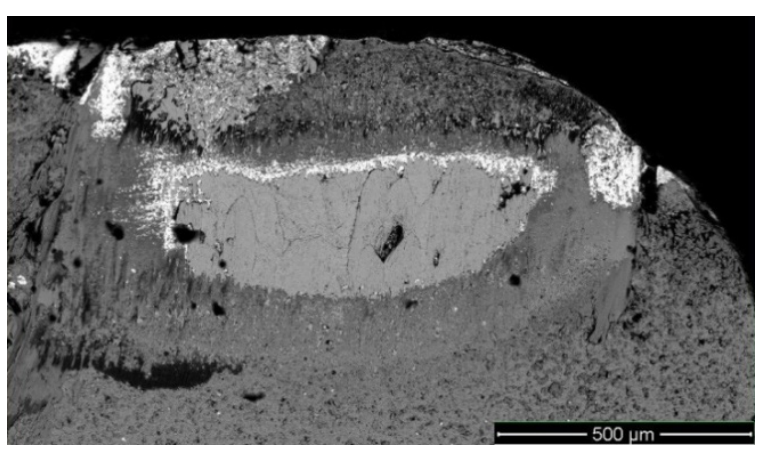

(b)

Figure 7. Contact pads on the rake faces of the carbide tools with coatings (a) Ti-TiN-(Ti,Cr,Mo,Al)N and $(\mathbf{b})(\mathrm{Ti}, \mathrm{Al}) \mathrm{N}$ after 16 min of cutting.

Figures 8 and 9 exhibit the results of the investigation of the fracture pattern on the rake and flank faces of the carbide tools.

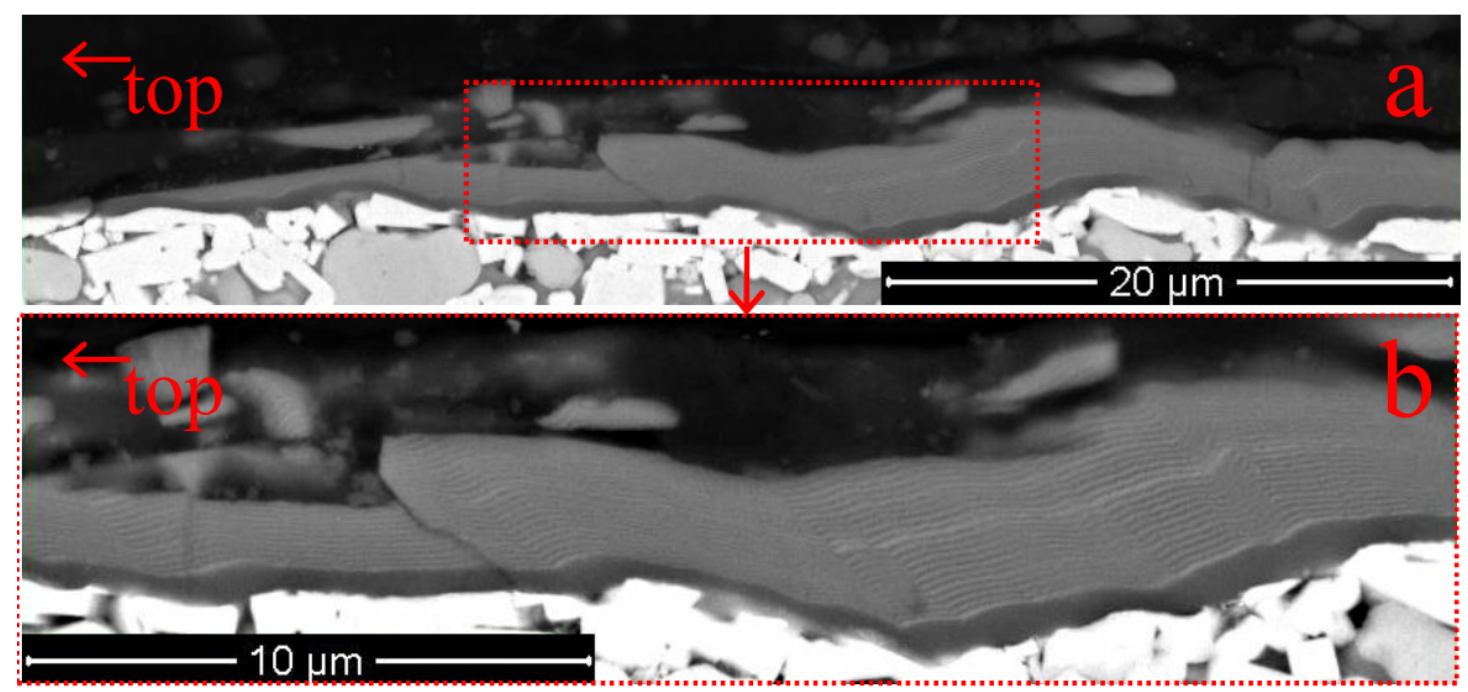

Figure 8. Fracture patterns for Ti-TiN-(Ti,Cr,Mo,Al) N coating $(\mathbf{a}, \mathbf{b})$ on the flank faces of the tools $\left(90^{\circ}\right.$ counterclockwise, top left (SEM).

The study of the fracture pattern finds that, given the noticeable microdeformations in the structure of the carbide substrate, Ti-TiN-(Ti,Cr,Mo,Al)N coatings are characterised by sufficient ductility and resistance to brittle fracture.

The study of the fracture patterns on the Ti-TiN-(Ti,Cr,Mo,Al) N coatings on the rake faces of the tools (Figure 9) finds that the fracture process is accompanied by active cracking. The Ti-TiN-(Ti,Cr,Mo,Al)N coating exhibits both inclined and transverse cracks (Figure 9). On the Ti-TiN-(Ti,Cr,Mo,Al)N coating, the brittle fracture accompanied by chipping of some fragments is typical (Figure $9 \mathrm{~b}-\mathrm{e}$ ). Figure $9 \mathrm{a}$ illustrates that the wear surface of the coating on the boundary of its fracture is quite smooth and there are signs of local chipping of coating fragments. 

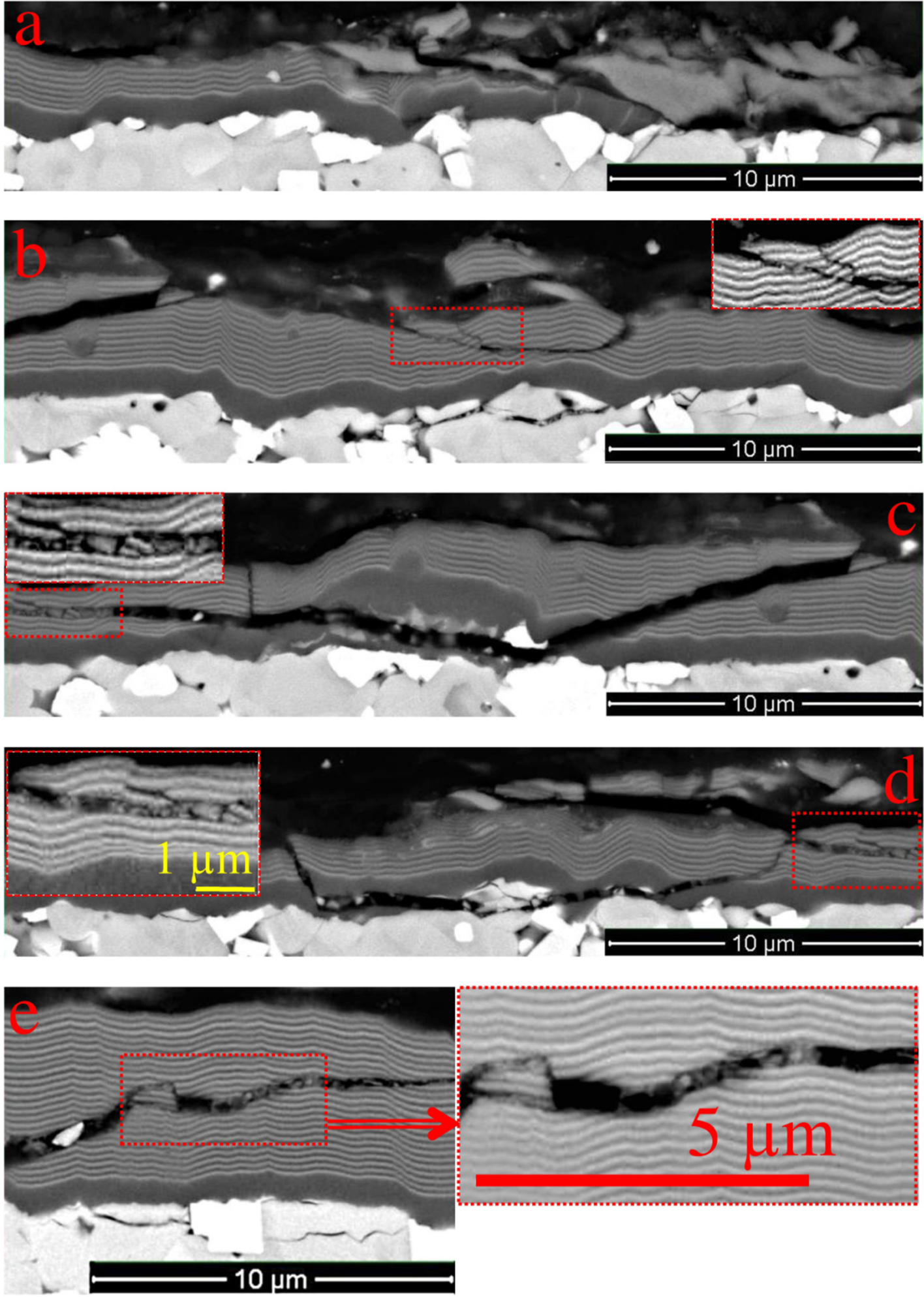

Figure 9. Fracture pattern for coating $\mathrm{Ti}-\mathrm{TiN}-(\mathrm{Ti}, \mathrm{Cr}, \mathrm{Mo}, \mathrm{Al}) \mathrm{N}$ on the rake face of the carbide tool (SEM), (a) the nature of destruction of the coating at the boundary of the crater of wear, $(\mathbf{b}-\mathbf{e})$ the nature of cracking in the structure of the coating.

After cutting, delaminations and longitudinal cracks also occur in the structure of the coating on the cutting tool, and the study of them on the rake face of the tool is depicted in Figure 10. The upper part of the image demonstrates a delamination between nanolayers (see Box A for a larger scale). 
The delamination occurs not only along the border of two nanolayer periods, but also along the border of individual nanolayers. At the same time, the delamination does not transform into a longitudinal crack, that it, does not cut the nanolayers. As noted earlier [8,30,31,35], such delaminations can reduce the level of internal stresses and can thus play some positive role by slowing down the process of coating fracture. The lower part of the image depicts a delamination transforming into a transverse crack (see Box B for details). The formation of such cracks may be associated with the effect of residual longitudinal compressive stresses. Another reason for the formation of delaminations and longitudinal cracks can be transverse cyclic tensile stresses formed under the influence of adhesive fatigue wear processes arising during cutting $[8,30,31,35,48]$.
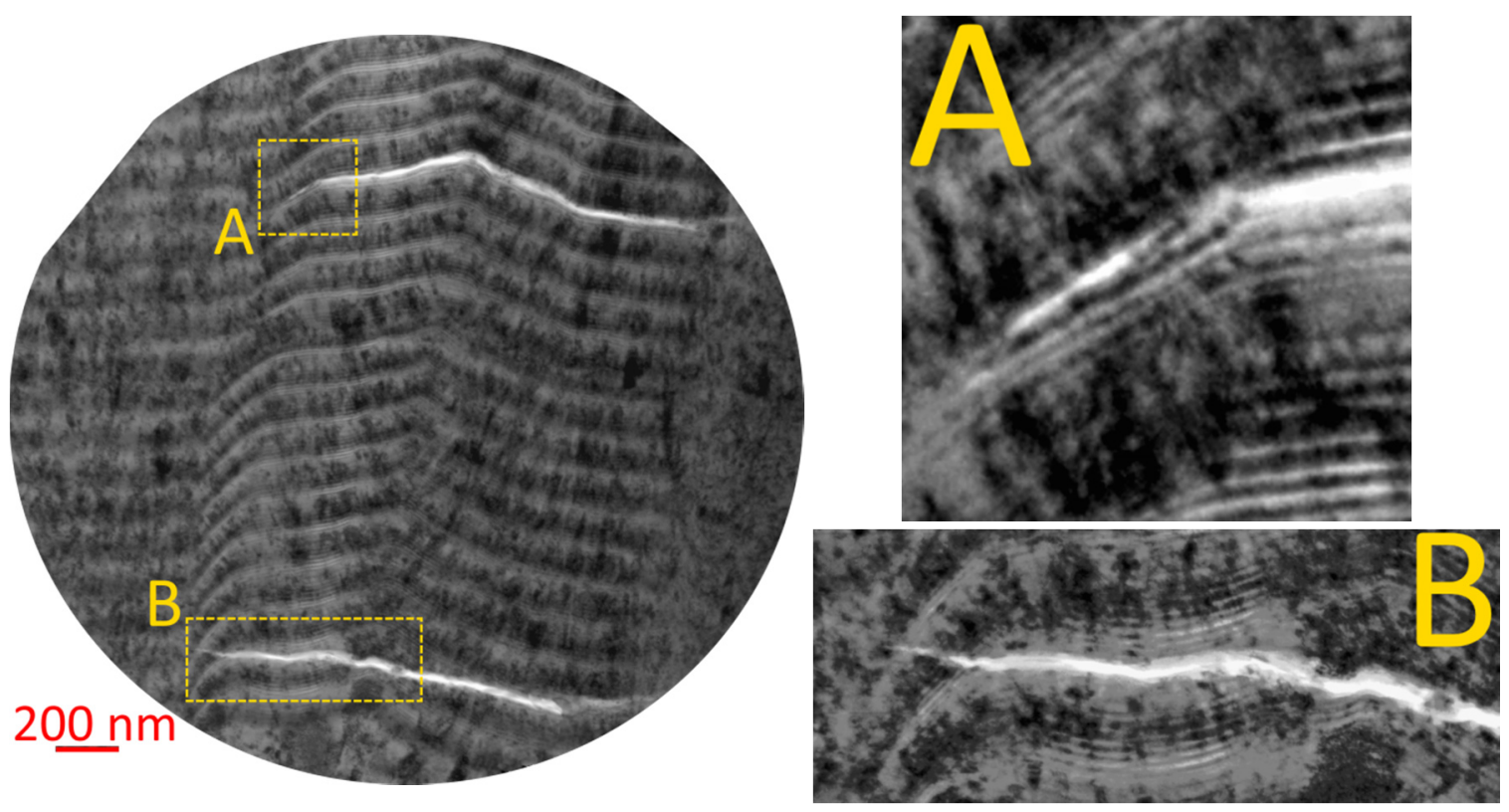

Figure 10. Pattern of the formation of longitudinal cracks and delaminations in the Ti-TiN( $\mathrm{Ti}, \mathrm{Cr}, \mathrm{Mo}, \mathrm{Al}) \mathrm{N}$ coating on the rake face of the tool (TEM). (A) inter nanolayer delamination (B) nanolayer cut by a crack.

\section{Conclusions}

The properties of the Ti-TiN-(Ti,Cr,Mo,Al)N multilayered composite coating with a wear-resistant layer of nanolayer structure were studied. The conducted studies have found the following:

(1) The average coating hardness was $42 \pm 1.3 \mathrm{GPa}$.

(2) The value of nanolayer period $\lambda$ is about $120 \mathrm{~nm}$, and the thicknesses of nanolayers are within the range of $1-8 \mathrm{~nm}$.

(3) The studies of the phase composition of the coating have revealed the presence of a main cubic phase of $(\mathrm{Ti}, \mathrm{Nb}, \mathrm{Zr}, \mathrm{Al}) \mathrm{N}$ with Fm3m space group. Weak reflections with P6.3mc space group belong to the h-AlN phase.

(4) It is found that the grain sizes in the coating under study can significantly exceed the thicknesses of its nanolayers and the value of nanolayer period $\lambda$. While nano-sized grains (5-15 $\mathrm{nm})$ are detected, there are also columnar crystals 1-2 $\mu \mathrm{m}$ long.

(5) After 16 min of cutting, the wear rate for the tool with the Ti-TiN-(Ti,Cr,Mo,Al)N coating was 1.9 times lower compared to the wear rate for a tool with the (Ti,Al)N commercial monolithic coating.

(6) The cracking patterns in the coating on the rake and flank faces of the tool demonstrate a considerably brittle nature of fracture, accompanied by the chipping of separate fragments of the coating. At the same time, delaminations between nanolayers of the coating were also detected. 
Author Contributions: Conceptualization, A.V. and S.G.; methodology, S.G. and A.V.; formal analysis, F.M., C.S. and I.S.; investigation, F.M., N.S., J.B., N.A., G.O. and I.S.; resources, S.G.; data curation, A.V. and G.O.; writing—original draft preparation, A.V.; writing—review and editing, A.V.; project administration S.G, A.V. and C.S.; funding acquisition, S.G. All authors have read and agreed to the published version of the manuscript.

Funding: This research was funded by Ministry of Science and Higher Education of the Russian Federation, Grant No. 0707-2020-0025.

Conflicts of Interest: The authors declare no conflict of interest.

\section{References}

1. Aydin, M.; Karakuzu, C.; Uçar, M.; Cengiz, A.; Çavuşlu, M.A. Prediction of surface roughness and cutting zone temperature in dry turning processes of AISI304 stainless steel using ANFIS with PSO learning. Int. J. Adv. Manuf. Technol. 2013, 67, 957-967. [CrossRef]

2. Stephenson, D.A. Inverse method for investigating deformation zone temperatures in metal cutting. J. Eng. Ind. Trans. ASME 1991, 113, 129-136. [CrossRef]

3. Shi, B.; Attia, H.; Tounsi, N. Identification of material constitutive laws for machining-Part I: An analytical model describing the stress, strain, strain rate, and temperature fields in the primary shear zone in orthogonal metal cutting. J. Manuf. Sci. Eng. 2010, 132, 051008. [CrossRef]

4. Grzesik, W.; Bartoszuk, M.; Nieslony, P. Finite element modelling of temperature distribution in the cutting zone in turning processes with differently coated tools. J. Mater. Process. Technol. 2005, 164-165, 1204-1211. [CrossRef]

5. Kuzin, V.V.; Grigoriev, S.N.; Fedorov, M.Y. Role of the thermal factor in the wear mechanism of ceramic tools. Part 2: Microlevel. J. Frict. Wear 2015, 36, 40-44. [CrossRef]

6. Zheng, G.; Xu, R.; Cheng, X.; Zhao, G.; Li, L.; Zhao, J. Effect of cutting parameters on wear behavior of coated tool and surface roughness in high-speed turning of 300M. Measurement 2018, 125, 99-108. [CrossRef]

7. Vennemann, A.; Stock, H.-R.; Kohlscheen, J.; Rambadt, S.; Erkens, G. Oxidation resistance of titanium-aluminium-silicon nitride coatings. Surf. Coat. Technol. 2003, 174-175, 408-415. [CrossRef]

8. Vereschaka, A.; Tabakov, V.; Grigoriev, S.; Sitnikov, N.; Milovich, F.; Andreev, N.; Bublikov, J. Investigation of wear mechanisms for the rake face of a cutting tool with a multilayer composite nanostructured $\mathrm{Cr}-\mathrm{CrN}-(\mathrm{Ti}, \mathrm{Cr}, \mathrm{Al}, \mathrm{Si}) \mathrm{N}$ coating in high-speed steel turning. Wear 2019, 438-439, 203069. [CrossRef]

9. Vereschaka, A.; Tabakov, V.; Grigoriev, S.; Sitnikov, N.; Andreev, N.; Milovich, F. Investigation of wear and diffusion processes on rake faces of carbide inserts with Ti-TiN-(Ti,Al,Si)N composite nanostructured coating. Wear 2018, 416-417, 72-80. [CrossRef]

10. Volosova, M.A.; Grigor'ev, S.N.; Kuzin, V.V. Effect of Titanium Nitride Coating on Stress Structural Inhomogeneity in Oxide-Carbide Ceramic. Part 4. Action of Heat Flow. Refract. Ind. Ceram. 2015, 56, 91-96. [CrossRef]

11. Grigoriev, S.; Vereschaka, A.; Milovich, F.; Tabakov, V.; Sitnikov, N.; Andreev, N.; Sviridova, T.; Bublikov, J. Investigation of multicomponent nanolayer coatings based on nitrides of $\mathrm{Cr}, \mathrm{Mo}, \mathrm{Zr}, \mathrm{Nb}$, and $\mathrm{Al}$. Surf. Coat. Technol. 2020, 401, 126258. [CrossRef]

12. Grigoriev, S.N.; Volosova, M.A.; Vereschaka, A.A.; Sitnikov, N.N.; Milovich, F.; Bublikov, J.I.; Fyodorov, S.V.; Seleznev, A.E. Properties of (Cr,Al,Si)N-(DLC-Si) composite coatings deposited on a cutting ceramic substrate. Ceram. Int. 2020, 46, 18241-18255. [CrossRef]

13. Grigoriev, S.N.; Sobol, O.V.; Beresnev, V.M.; Serdyuk, I.V.; Pogrebnyak, A.D.; Kolesnikov, D.A.; Nemchenko, U.S. Tribological characteristics of (TiZrHfVNbTa)N coatings applied using the vacuum arc deposition method. J. Frict. Wear 2014, 35, 359-364. [CrossRef]

14. Vereschaka, A.A.; Grigoriev, S.N.; Sitnikov, N.N.; Oganyan, G.V.; Batako, A. Working efficiency of cutting tools with multilayer nano-structured Ti-TiCN-(Ti,Al)CN and Ti-TiCN-(Ti,Al,Cr)CN coatings: Analysis of cutting properties, wear mechanism and diffusion processes. Surf. Coat. Technol. 2017, 332, $198-213$. [CrossRef]

15. Vereschaka, A.S.; Grigoriev, S.N.; Tabakov, V.P.; Sotova, E.S.; Vereschaka, A.A.; Kulikov, M.Y. Improving the efficiency of the cutting tool made of ceramic when machining hardened steel by applying nano-dispersed multi-layered coatings. Key Eng. Mater. 2014, 581, 68-73. [CrossRef] 
16. Regent, F.; Musil, J. Magnetron sputtered Cr-Ni-N and Ti-Mo-N films: Comparison of mechanical properties. Surf. Coat. Technol. 2001, 142-144, 146-151. [CrossRef]

17. Kuleshov, A.K.; Uglov, V.V.; Chayevski, V.V.; Anishchik, V.M. Properties of coatings based on Cr, Ti, and Mo nitrides with embedded metals deposited on cutting tools. J. Frict. Wear 2011, 32, 192-198. [CrossRef]

18. Hangwei, C.; Yuan, G.; Lin, Y.; Zhikang, M.; Chenglei, W. High-temperature oxidation behavior of (Ti,Cr)N coating deposited on 4Cr13 stainless steel by multi-arc ion plating. Rare Metal Mater. Eng. 2014, 43, 1084-1087. [CrossRef]

19. Panjan, P.; Navinsek, B.; Cvelbar, A.; Zalar, A.; Milosev, I. Oxidation of TiN, ZrN, TiZrN, CrN, TiCrN and TiN/CrN multilayer hard coatings reactively sputtered at low temperature. Thin Solid Films 1996, 281-282, 298-301. [CrossRef]

20. Caplan, D.; Cohen, M. The Volatilization of Chromium Oxide. J. Electrochem. Soc. 1961, 108, 438-442. [CrossRef]

21. Gu, B.; Tu, J.P.; Zheng, X.H.; Yang, Y.Z.; Peng, S.M. Comparison in mechanical and tribological properties of Cr-W-N and Cr-Mo-N multilayer films deposited by DC reactive magnetron sputtering. Surf. Coat. Technol. 2008, 202, 2189-2193. [CrossRef]

22. Kim, K.H.; Choi, E.Y.; Hong, S.G.; Park, B.G.; Yoon, J.H.; Yong, J.H. Syntheses and mechanical properties of Cr-Mo-N coatings by a hybrid coating system. Surf. Coat. Technol. 2006, 207, 4068-4072. [CrossRef]

23. Qi, D.; Lei, H.; Wang, T.; Pei, Z.; Gong, J.; Sun, C. Mechanical, microstructural and tribological properties of reactive magnetron sputtered Cr-Mo-N films. J. Mater. Sci. Technol. 2015, 31, 55-64. [CrossRef]

24. Koshy, R.A.; Graham, M.E.; Marks, L.D. Temperature activated self-lubrication in $\mathrm{CrN} / \mathrm{Mo}_{2} \mathrm{~N}$ nanolayer coatings. Surf. Coat. Technol. 2010, 204, 1359-1365. [CrossRef]

25. Sergevnin, V.S.; Blinkov, I.V.; Belov, D.S.; Volkhonskii, A.O.; Skryleva, E.A.; Chernogor, A.V. Phase formation in the Ti-Al-Mo-N system during the growth of adaptive wear-resistant coatings by arc PVD. Inorg. Mater. 2016, 52, 735-742. [CrossRef]

26. Tomaszewski, L.; Gulbinski, W.; Urbanowicz, A.; Suszko, T.; Lewandowski, A.; Gulbinski, W. TiAlN based wear resistant coatings modified by molybdenum addition. Vacuum 2015, 121, 223-229. [CrossRef]

27. Yang, K.; Xian, G.; Zhao, H.; Fan, H.; Wang, J.; Wang, H.; Du, H. Effect of Mo content on the structure and mechanical properties of TiAlMoN films deposited on WC-Co cemented carbide substrate by magnetron sputtering. Int. J. Refract. Met. Hard Mater. 2015, 52, 29-35. [CrossRef]

28. Sergevnin, V.S.; Blinkov, I.V.; Volkhonskii, A.O.; Belov, D.S.; Kuznetsov, D.V.; Gorshenkov, M.V.; Skryleva, E.A. Wear behaviour of wear-resistant adaptive nano-multilayeredTi-Al-Mo-N coatings. Appl. Surf. Sci. 2016, 388, 13-23. [CrossRef]

29. Sergevnin, V.S.; Blinkov, I.; Volkhonskii, A.; Belov, D.; Chernogor, A. Structure formation of adaptive arc-PVD Ti-Al-Mo-N and Ti-Al-Mo-Ni-N coatings and their wear-resistance under various friction conditions. Surf. Coat. Technol. 2019, 376, 38-43. [CrossRef]

30. Vereschaka, A.; Tabakov, V.; Grigoriev, S.; Sitnikov, N.; Oganyan, G.; Andreev, N.; Milovich, F. Investigation of wear dynamics for cutting tools with multilayer composite nanostructured coatings in turning constructional steel. Wear 2019, 17-37. [CrossRef]

31. Grigoriev, S.N.; Vereschaka, A.A.; Fyodorov, S.V.; Sitnikov, N.N.; Batako, A.D. Comparative analysis of cutting properties and nature of wear of carbide cutting tools with multi-layerednano-structured and gradient coatings produced by using of various deposition methods. Int. J. Adv. Manuf. Technol. 2017, 90, 3421-3435. [CrossRef]

32. Vereschaka, A.; Grigoriev, S.N.; Volosova, M.A.; Batako, A.; Vereschaka, A.S.; Sitnikov, N.; Seleznev, A. Nano-scale multi-layered coatings for improved efficiency of ceramic cutting tools. Int. J. Adv. Manuf. Technol. 2016, 90, $27-43$. [CrossRef]

33. Vereschaka, A.; Bublikov, J.I.; Sitnikov, N.N.; Oganyan, G.V.; Sotova, C.S. Influence of nanolayer thickness on the performance properties of multilayer composite nano-structured modified coatings for metal-cutting tools. Int. J. Adv. Manuf. Technol. 2017, 95, 2625-2640. [CrossRef]

34. Vereschaka, A.A. Development of Assisted Filtered Cathodic Vacuum Arc Deposition of Nano-Dispersed Multi-Layered Composite Coatings on Cutting Tools. Key Eng. Mater. 2013, 581, 62-67. [CrossRef]

35. Vereschaka, A.; Tabakov, V.; Grigoriev, S.; Aksenenko, A.; Sitnikov, N.; Oganyan, G.; Seleznev, A.; Shevchenko, S. Effect of adhesion and the wear-resistant layer thickness ratio on mechanical and performance properties of $\mathrm{ZrN}-(\mathrm{Zr}, \mathrm{Al}, \mathrm{Si}) \mathrm{N}$ coatings. Surf. Coat. Technol. 2019, 357, 218-234. [CrossRef] 
36. Metel, A.S.; Bolbukov, V.P.; Volosova, M.A.; Grigoriev, S.N.; Melnik, Y.A. Equipment for deposition of thin metallic films bombarded by fast argon atoms. Instrum. Exp. Tech. 2014, 57, 345-351. [CrossRef]

37. Sobol', O.V.; Andreev, A.A.; Grigoriev, S.N.; Stolbovoy, V.A.; Volosova, M.A.; Aleshin, S.V.; Gorban', V.F. Physical characteristics, structure and stress state of vacuum-arc tin coating, deposition on the substrate when applying high-voltage pulse during the deposition. Probl. At. Sci. Technol. 2011, 4, 174-177.

38. Kuzin, V.V.; Grigor'ev, S.N.; Volosova, M.A. Effect of a TiC Coating on the Stress-Strain State of a Plate of a High-Density Nitride Ceramic Under NonsteadyThermoelastic Conditions. Refract. Ind. Ceram. 2014, 54, 376-380. [CrossRef]

39. Metel, A.S.; Grigoriev, S.N.; Melnik, Y.A.; Bolbukov, V.P. Broad beam sources of fast molecules with segmented cold cathodes and emissive grids. Instrum. Exp. Tech. 2012, 55, 122-130. [CrossRef]

40. Metel, A.S.; Bolbukov, V.P.; Volosova, M.A.; Grigoriev, S.N.; Melnik, Y.A. Source of metal atoms and fast gas molecules for coating deposition on complex shaped dielectric products. Surf. Coat. Technol. 2013, 225, 34-39. [CrossRef]

41. Metel, A.S.; Melnik, Y.; Metel, A. Broad fast neutral molecule beam sources for industrial-scale beam-assisted deposition. Surf. Coat. Technol. 2002, 156, 44-49. [CrossRef]

42. Pogrebnjak, A.; Bagdasaryan, A.; Beresnev, V.; Nyemchenko, U.; Ivashchenko, V.; Kravchenko, Y.; Shaimardanov, Z.; Plotnikov, S.; Maksakova, O. The effects of $\mathrm{Cr}$ and $\mathrm{Si}$ additions and deposition conditions on the structure and properties of the (Zr-Ti-Nb)N coatings. Ceram. Int. 2017, 43, 771-782. [CrossRef]

43. Glatz, S.A.; Moraes, V.; Koller, C.M.; Riedl, H.; Bolvardi, H.; Kolozsvári, S.; Mayrhofer, P.H. Effect of Mo on the thermal stability, oxidation resistance, and tribo-mechanical properties of arc evaporated Ti-Al-N coatings. J. Vac. Sci. Technol. A 2017, 35, 061515. [CrossRef]

44. Lu, Y.-C.; Chen, H.-W.; Chang, C.-C.; Wu, C.-Y.; Duh, J.-G. Tribological properties of nanocomposite Cr-Mo-Si-N coatings at elevated temperature through silicon content modification. Surf. Coat. Technol. 2018, 338, 69-74. [CrossRef]

45. Voevodin, A.; Muratore, C.; Aouadi, S. Hard coatings with high temperature adaptive lubrication and contact thermal management: Review. Surf. Coat. Technol. 2014, 257, 247-265. [CrossRef]

46. Hovsepian, P.; Lewis, D.; Luo, Q.; Münz, W.-D.; Mayrhofer, P.; Mitterer, C.; Zhou, Z.; Rainforth, W. TiAlN based nanoscale multilayer coatings designed to adapt their tribological properties at elevated temperatures. Thin Solid Films 2005, 485, 160-168. [CrossRef]

47. Voevodin, A.A.; Zabinski, J.S. Supertough wear-resistant coatings with 'chameleon' surface adaptation. Thin Solid Films 2000, 370, 223-231. [CrossRef]

48. Vereschaka, A. Improvement of Working Efficiency of Cutting Tools by Modifying its Surface Properties by Application of Wear-Resistant Complexes. Adv. Mater. Res. 2013, 712, 347-351. [CrossRef]

Publisher's Note: MDPI stays neutral with regard to jurisdictional claims in published maps and institutional affiliations.

(C) 2020 by the authors. Licensee MDPI, Basel, Switzerland. This article is an open access article distributed under the terms and conditions of the Creative Commons Attribution (CC BY) license (http://creativecommons.org/licenses/by/4.0/). 